\title{
PRAVNI POLOŽAJ KATOLIČKE CRKVE KAO GOSPODARSKOG SUBJEKTA U PRAVU EUROPSKE UNIJE I HRVATSKOM PRAVU
}

Doc. dr. sc. Tomislav Sokol *
Izv. prof. dr. sc. Frane Staničic **
UDK: 338.222:261.7(4EU:497.5)

334.7:261.7(4EU:497.5)

Izvorni znanstveni rad

Primljeno: prosinac 2017.

U radu se analizira primjenjivost pravnog okvira EU-a u području državnih potpora, tržišnog natjecanja i slobode kretanja usluga na djelatnost Katoličke Crkve, ponajprije s obzirom na pitanje obavlja li Katolička Crkva gospodarsku djelatnost i u kojem opsegu prema tom pravnom okviru, te se utvrđuje poštuje li Republika Hrvatska navedeni okvir i postoje li točke prijepora koje je potrebno pravno razriješiti. Ističu se nepoznanice koje praksa Suda Europske unije nije još do kraja razriješila, a tiču se primjenjivosti tržišnih pravila EU-a na vjerske zajednice. Također se prezentira skup pravnih pravila koja unutar Republike Hrvatske reguliraju položaj Katoličke Crkve, uz poseban naglasak na moguće točke prijepora u odnosu na pravo EU-a. Na kraju se predlažu moguća rješenja navedenih nejasnoća i prijepora, na europskoj i na nacionalnoj razini, sukladno načelu pravne sigurnosti kao iznimno bitnom za adresate predmetnih pravnih normi.

Ključne riječi: Katolička Crkva, državna potpora, gospodarska djelatnost, poduzetnik

* Dr. sc. Tomislav Sokol, docent, viši predavač Zagrebačke škole ekonomije i managementa, naslovni docent Hrvatskog katoličkog sveučilišta, Jordanovac 110, Zagreb; tsokol@zsem.hr;

ORCID ID: orcid.org/0000-0002-3592-2967

** Dr. sc. Frane Staničić, izvanredni profesor Pravnog fakulteta Sveučilišta u Zagrebu, Sv. Ćirila i Metoda 4, Zagreb; frane.stanicic@pravo.hr;

ORCID ID: orcid.org/0000-0001-8304-7901 


\section{UVOD}

Uređenje pravnog položaja Katoličke Crkve u zemljama Europske unije primarno je u nadležnosti država članica. Navedeno pitanje uređeno je u Republici Hrvatskoj međunarodnim ugovorima između Republike Hrvatske i Svete Stolice, kao i zakonima donesenim od strane Hrvatskog sabora. ${ }^{1}$ Ipak, pravni okvir Europske unije svakako utječe na pravni položaj Katoličke Crkve u Republici Hrvatskoj, primarno kroz primjenu pravila o tržišnom natjecanju i državnim potporama te slobodi kretanja na unutarnjem tržištu.

Cilj je ovog rada analizirati primjenjivost pravnog okvira EU-a u području državnih potpora, tržišnog natjecanja i slobode kretanja usluga na djelatnost Katoličke Crkve, ponajprije kroz pitanje obavlja li Katolička Crkva gospodarsku djelatnost i u kojem opsegu prema tom pravnom okviru, utvrditi poštuje li Republika Hrvatska navedeni okvir te postoje li određene točke prijepora koje je potrebno pravno razriješiti.

U drugom poglavlju, nakon uvoda, analizira se pravni okvir Europske unije u području državnih potpora i slobode kretanja usluga, uz naglasak na pitanje smatra li se Katolička Crkva poduzetnikom (koji obavlja gospodarsku djelatnost) na kojeg se primjenjuju relevantna pravila europskog prava. Pri tome se posebno ističu određene nepoznanice koje praksa Suda Europske unije nije još do kraja razriješila, a tiču se primjenjivosti tržišnih pravila EU-a na vjerske zajednice. U trećem poglavlju prezentiran je skup pravnih pravila koja unutar Republike Hrvatske reguliraju položaj Katoličke Crkve, uz poseban naglasak na moguće točke prijepora u odnosu na pravo EU-a. U idućem poglavlju prezentirana su moguća rješenja navedenih nejasnoća i prijepora, na europskoj i na nacionalnoj razini, sukladno načelu pravne sigurnosti kao iznimno bitnom za adresate predmetnih pravnih normi.

\section{PRAVNI OKVIR EUROPSKE UNIJE}

\subsection{Gospodarska djelatnost}

Čl. 107. Ugovora o funkcioniranju Europske unije propisuje da je nespojiva s unutarnjim tržištem Europske unije ona potpora koju poduzetniku dodijeli država članica EU-a ili koja se dodjeljuje kroz državna sredstava u bilo kojem obliku kojim se narušava ili prijeti da će se narušiti tržišno natjecanje stavljanjem samo određenih poduzetnika ili proizvodnje neke robe u povoljniji položaj. Ta-

1 Vidi, primjerice, Zakon o potvrđivanju Ugovora između Svete Stolice i Republike Hrvatske o pravnim pitanjima (Narodne novine, Međunarodni ugovori, br. 3/1997). 
kva potpora zabranjena je u onoj mjeri u kojoj utječe na trgovinu između država članica EU-a, osim ako je Ugovorima predviđeno drukčije. ${ }^{2}$

Prvi korak u utvrđivanju je li riječ o zabranjenoj državnoj potpori sastoji se $u$ utvrđivanju je li u pojedinom slučaju riječ o poduzetniku. Bitno je napomenuti da pojam "poduzetnik" nije definiran odredbama Ugovora te je za njegovo shvaćanje potrebno okrenuti se sudskoj praksi i drugim službenim dokumentima Europske unije. Polazna točka u tom smislu predstavlja odluka Suda Europske unije u predmetu Höfner, vezanom uz zaštitu tržišnog natjecanja. U tom slučaju Sud je odredio da se poduzetnikom smatra svaki subjekt koji je uključen u određenu gospodarsku djelatnost, bez obzira na pravni status (primjerice, javni ili privatni) tog subjekta i njegov način financiranja. ${ }^{3}$ Navedena definicija je vrlo široka te $u$ praksi može obuhvatiti svaku osobu koja obavljanjem gospodarske djelatnosti sudjeluje u prometu usluga i roba. ${ }^{4}$ Riječ je o funkcionalnom pristupu, u kojem je naglasak na djelatnosti koju obavlja subjekt, pri čemu se uzima u obzir ukupnost svih činjenica i gospodarskih okolnosti slučaja. ${ }^{5}$ Pri tome je važno napomenuti

2 Vidi Pročišćene verzije Ugovora o Europskoj uniji i Ugovora o funkcioniranju Europske unije, Ugovor o Europskoj uniji [2016.], Službeni list br. C202/1. Ovdje je riječ zapravo o četirima kumulativnim uvjetima koji moraju biti ispunjeni da bi bila riječ o zabranjenoj državnoj potpori: mora biti riječ o ekonomskoj prednosti koju poduzetnik ne bi stekao u normalnim tržišnim uvjetima (ekonomska prednost); mora biti riječ o ekonomskoj prednosti koju je u nekom obliku, bilo izravno bilo neizravno, dala država transferom državnih sredstava (državno podrijetlo); mora biti riječ o mjeri koja daje prednost određenim poduzetnicima u odnosu na druge (selektivnost); mora rezultirati narušavanjem tržišnog natjecanja ili dovesti do opasnosti od narušavanja tržišnog natjecanja uz postojanje stvarnog ili samo potencijalnog učinka na trgovinu među državama članicama Europske unije (učinak na trgovinu i tržišno natjecanje).

3 Vidi Predmet C-41/90 Klaus Höfner and Fritz Elser v Macrotron GmbH [1991.] ECR I-1979. Vidi i Odudu, O., Are State-Owned Health-Care Providers Undertakings Subject to Competition Law?, European Competition Law Review, vol. 48, br. 5, 2011., str. 231 - 241. Treba naglasiti da se zaposlenici i potrošači općenito ne smatraju poduzetnicima u ovom smislu. Vidi Townley, C., The Concept of an 'Undertaking': The Boundaries of the Corporation - A Discussion of Agency, Employees and Subsidiaries, u: Amato, G.; Ehlermann, C., (ur.), EC Competition Law: A Critical Assessment, Hart Publishing, Oxford, 2007., str. 23. Vidi također, primjerice, Poščić, A., Dokazivanje predatornih cijena u europskom pravu tržišnog natjecanja, Zbornik radova Pravnog fakulteta u Splitu, vol. 49, br. 3, 2012., str. 553 - 573, i Jones, A.; Sufrin, B., EU Competition Law: Text, Cases and Materials, Oxford University Press, Oxford, 2014., str. 127.

4 Vidi, primjerice, Cerovac, M., Pravo tržišnog natjecanja u EU, u: Mintas Hodak, Lj., (ur.), Europska unija, MATE, Zagreb, 2010., str. 255.

5 Vidi Cerovac, M., Pojam poduzetnika u pravu tržišnog natjecanja, Hrvatska pravna revija, br. 10, 2005., str. 60 - 70, i Poščić, A., Pojam poduzetnika u europskom pravu tržišnog 
da su definicija i kriteriji isti u kontekstu prava tržišnog natjecanja i državnih potpora, te nema potrebe raditi distinkciju između tih dvaju konteksta. ${ }^{6}$

Sudska praksa nije jednoznačno odredila kada određeni subjekt predstavlja poduzetnika. Umjesto toga, kroz nju se iskristaliziralo nekoliko kriterija koji, u različitim kombinacijama, ovisno o okolnostima pojedinog slučaja, znače da u tom slučaju nije ili jest riječ o poduzetniku. Jedan od kriterija koji se mogu spomenuti je socijalna svrha odnosno funkcija subjekta. Navedeni kriterij prvi put je, kao relevantan, spomenut u predmetu Poucet $i$ Pistre, u kontekstu javnog socijalnog osiguranja. U tom predmetu Sud je utvrdio da obvezni sustav javnog socijalnog osiguranja zbog svoje socijalne funkcije ne predstavlja gospodarsku djelatnost prema pravu Europske unije te se osiguravatelji u takvom sustavu ne smatraju poduzetnicima. ${ }^{7} \mathrm{~S}$ druge strane, u slučaju dobrovoljnog životnog osiguranja, unatoč njegovoj socijalnoj svrsi, riječ je o gospodarskoj aktivnosti te su pravila o tržišnom natjecanju EU-a primjenjiva na takvu situaciju. ${ }^{8}$ Ukratko, socijalna funkcija određenog subjekta jest kriterij pri utvrđivanju je li riječ o poduzetniku, no nije jedini kriterij sam po sebi dovoljan da bi se isključila primjena pravila o tržišnom natjecanju i državnim potporama.

S kriterijem socijalne funkcije subjekta usko je povezan kriterij solidarnosti. Prema Sudu Europske unije solidarnost postoji u slučajevima socijalnih osiguranja financiranih doprinosima koji su proporcionalni prihodu osoba koje uplaćuju navedene doprinose. Kod zdravstvenog osiguranja posebno je bitno da se osobe s vrlo malim dohotkom mogu i osloboditi obveze plaćanja doprinosa, dok davanja ostaju jednaka za sve osobe koje ih primaju. U opisanom slučaju riječ je zapravo o redistribuciji između osoba koje imaju mogućnost uplaćivanja potrebnih doprinosa (proporcionalnih dohotku) i osoba koje, zbog nedovoljnih vlastitih resursa, ne bi bile u stanju same snositi trošak socijalnih davanja. Kod

natjecanja, Zbornik Pravnog fakulteta Sveučilišta u Rijeci, vol. 29, br. 2, 2008., str. 917 - 939 .

6 Vidi Obavijest Komisije o pojmu državne potpore iz članka 107. stavka 1. Ugovora o funkcioniranju Europske unije [2016.], Službeni list br. C262/01.

7 Vidi spojene predmete C-159/91 i C-160/91 Christian Poucet v Assurances Générales de France and Caisse Mutuelle Régionale du Languedoc-Roussillon [1993.], ECR I-637, točka 8. Vidi također Đulabić, V., Socijalne službe u konceptu službi od općeg interesa, Revija za socijalnu politiku, vol. 14, br. 2, 2007., str. 137 - 162, i Klarić, M.; Nikolić, M., Ustrojstvo javnih službi u Europskom pravnom poretku, Zbornik radova Pravnog fakulteta u Splitu, vol. 48, br. 1, 2011., str. 89 - 102.

8 Vidi predmet C-244/94 Fédération Française des Sociétés d'Assurance, Société Paternelle-Vie, Union des Assurances de Paris-Vie and Caisse d'Assurance et de Prévoyance Mutuelle des Agriculteurs v Ministère de l'Agriculture et de la Pêche [1995.], ECR I-4013, točke $17-20$. 
starosne mirovine solidarnost proizlazi iz toga što radnici plaćaju doprinose za osobe koje su trenutačno u mirovini (međugeneracijska solidarnost). U navedenim situacijama fondovi zdravstvenog i mirovinskog osiguranja (osiguravatelji) ne predstavljaju poduzetnike na koje se primjenjuju propisi EU-a o zaštiti tržišnog natjecanja i državnim potporama. ${ }^{9}$ Može se, međutim, dogoditi i da subjekt koji djeluje sukladno načelu solidarnosti obavlja gospodarsku aktivnost i predstavlja poduzetnika. Takva je situacija, primjerice, u sustavu dobrovoljnog osiguranja utemeljenom na načelu kapitalizacije. U takvom je sustavu načelo solidarnosti ograničeno, što posebno proizlazi iz dobrovoljnosti, te je riječ o gospodarskoj aktivnosti. $^{10}$

Postojanje solidarnosti nije relevantno samo u slučaju fondova mirovinskog i zdravstvenog osiguranja. Iznimno je bitna primjena opisanog načela u kontekstu samih pružatelja određenih javnih usluga. Ovdje se potrebno osvrnuti na presudu Općeg suda, potvrđenu od strane Suda, u predmetu FENIN. Bila je riječ o tužbi zbog predugih rokova plaćanja protiv Europske komisije od strane udruženja distributera medicinskih proizvoda i opreme koje su prodavali španjolskim bolnicama. Bila je riječ o jedinstvenom nacionalnom zdravstvenom sustavu $u$ kojem nije postojala distinkcija između pružatelja zdravstvenih usluga i fonda koji plaća navedene usluge. Premda je španjolski zdravstveni sustav kupovao dobra na tržištu, navedena transakcija sama po sebi nije značila da taj sustav obavlja gospodarsku djelatnost. Bitna je bila svrha za koju su dobra kupljena, a ta svrha bila je socijalna. Osim navedenog, ključnim se pokazala činjenica da je španjolski zdravstveni sustav utemeljen na načelu solidarnosti, s obzirom na to da je pretežno financiran od strane države i da je pacijentima pružao usluge besplatno. Ovdje je bitno napomenuti da stranke u postupku pred Komisijom nisu navele da su španjolske bolnice ponekad naplaćivale privatne zdravstvene usluge što su pružale osobama koje nisu obuhvaćene španjolskim zdravstvenim sustavom (poput stranih turista). Zbog navedenog razloga Opći sud nije se pozabavio tim pitanjem, premda je moguće da bi u kontekstu navedenih usluga bila riječ o gospodarskoj djelatnosti. ${ }^{11}$

9 Vidi Poucet i Pistre, op. cit. u bilj. 7, točke $10-11$.

10 Vidi Fédération Française des Sociétés d’Assurance, op. cit. u bilj. 8, točka 19.

11 Vidi predmet T-319/99 Federación Nacional de Empresas de Instrumentación Científica, Médica, Técnica y Dental (FENIN) v Commission of the European Communities [2003.], ECR II-357, točke 35 - 44, i predmet C-205/03 P Federación Española de Empresas de Tecnología Sanitaria (FENIN) v Commission of the European Communities [2006.], ECR I-6295. Na ovu temu vidi i, primjerice, Louri, V., The FENIN Judgment: The Notion of Undertaking and Purchasing Activity, Legal Issues of Economic Integration, vol. 32, 2005., str. 87 - 97. 
Osim socijalne svrhe i solidarnosti, pri određivanju je li riječ o poduzetniku bitno je i pitanje ostvarivanja dobiti. Kao i prethodni, ni taj kriterij nije apsolutan, već njegova prisutnost u nekim situacijama upućuje na nepostojanje gospodarske aktivnosti, a u nekima ne. Tako u spomenutim sustavima obveznog socijalnog osiguranja, utemeljenim na načelu solidarnosti bez namjere ostvarivanja dobiti, nije riječ o gospodarskoj djelatnosti. S druge strane, čak i sustavi obveznog socijalnog osiguranja utemeljeni na solidarnosti i bez namjere ostvarivanja dobiti obavljaju gospodarsku djelatnost u određenim slučajevima, kao što je bio slučaj u predmetu Albany. Konkretno, ako mirovinski fond sam određuje iznos doprinosa i davanja, koji ovisi o uspješnosti ulaganja na financijskom tržištu, on predstavlja poduzetnika bez obzira na sve kriterije opisane do sada. Bitno je također napomenuti da su, u navedenom predmetu, postojale određene iznimke od obveznosti osiguranja, što je također utjecalo na odluku Suda u tom slučaju. ${ }^{12}$

Idući kriterij koji se uzima u obzir pri isključenju primjene pravila o tržišnom natjecanju i državnim potporama jest kriterij državne kontrole. Navedeno se može vidjeti u odluci Suda Europske unije u predmetu Freskot. Bila je riječ o sustavu obveznog osiguranja od štete za poljoprivrednike. Navedeni sustav imao je socijalnu svrhu, no ključnim se pokazala činjenica da su iznosi doprinosa i davanja bili propisani nacionalnim zakonodavstvom. Fond koji je pružao davanja nije imao autonomiju u određivanju bitnih elemenata sustava osiguranja, te iz navedenog razloga nije bio poduzetnik u smislu prava Europske unije. ${ }^{13}$ Drugim riječima, postojanje državne kontrole nad djelovanjem određenog subjekta jedan je od indikatora za isključenje primjene pravila o tržišnom natjecanju i državnim potporama, zajedno s njegovom socijalnom funkcijom, postojanjem solidarnosti i neostvarivanjem dobiti.

Iz opisane sudske prakse teško je razlučiti univerzalni kriterij prema kojem bismo u svakom slučaju mogli bez greške utvrditi je li riječ o poduzetniku u

12 Vidi predmet C-67/96 Albany International BV v Stichting Bedriffspensioenfonds Textielindustrie [1999.], ECR I-5751, točke 81 - 86.

13 Vidi Predmet C-355/00 Freskot AE v Elliniko Dimosio [2003.], ECR I-5263, točke 76 - 79. Subjekti čije su sve aktivnosti povezane s njihovim specifičnim javnim ovlastima, poput kontrole zračnog prostora, također se ne smatraju poduzetnicima u kontekstu prava Europske unije. Vidi predmet C-364/92 SAT Fluggesellschaft mbH $v$ Eurocontrol [1994.], ECR I-0043, točke 19 - 31. U navedenom predmetu ključna je bila priroda same djelatnosti čija je svrha zaštite sigurnosti zračnog prometa nužno povezana s javnom vlasti te stoga nije riječ o gospodarskoj djelatnosti na koju se primjenjuju propisi EU-a o zaštiti tržišnog natjecanja i državnim potporama. O toj presudi vidi i, primjerice, Svetlicinii, A., Back to the Basics: Concepts of Undertaking and Economic Activity in the Selex Judgment, European Law Reporter, vol. 12, 2009., str. $422-427$. 
smislu prava Europske unije ili nije. Ipak, iz navedenog se može izvući općeniti zaključak da ključnu ulogu imaju propisi pojedine države koji u nekom segmentu praktički isključuju tržišno natjecanje. Država to može napraviti ili na način da potpuno zabrani konkurenciju i uspostavi zakonski monopol ili da stvori pravni okvir koji obavljanje određene aktivnosti čini posve neisplativim za privatne subjekte. Kada postoji stvarno tržišno natjecanje između određenog subjekta (čak i ako navedeni subjekt ima poseban pravni status ili predstavlja subjekt javnog prava) i privatnih osoba (fizičkih ili pravnih), može se zaključiti da je riječ o gospodarskoj djelatnosti na koju se primjenjuju propisi EU-a o tržišnom natjecanju i državnim potporama. U takvoj se situaciji subjekti koji se kroz pružanje dobara i usluga natječu s drugim subjektima na tržištu i snose rizik poslovanja smatraju poduzetnicima. ${ }^{14}$ Navedeno isključenje tržišnog natjecanja posebno je primjenjivo u slučaju subjekata koji ispunjavaju određenu socijalnu funkciju, djeluju prema načelu solidarnosti, ne ostvaruju dobit te čije su aktivnosti u bitnim elementima određene zakonodavstvom države članice Europske unije.

Pitanje obavljanja gospodarske djelatnosti i primjenjivosti tržišnih propisa EU-a nije ograničeno isključivo na sudsku praksu u sferi zaštite tržišnog natjecanja i državnih potpora. Bitnu ulogu ovdje igraju i pravila o slobodi kretanja usluga na unutarnjem tržištu Unije. Ključan predmet koji je utvrdio kriterije Suda Europske unije u ovom području jest Humbel, o slučaju francuskog državljanina koji je išao u srednju školu u Belgiji te je morao platiti školarinu (upisninu) koju nisu morali platiti belgijski državljani. Bila je riječ o očitoj diskriminaciji, no, da bi pravo EU-a bilo primjenjivo, među ostalim se moralo utvrditi je li riječ o slobodi pružanja usluga na unutarnjem tržištu EU-a, odnosno gospodarskoj djelatnosti. Sud je utvrdio da je riječ o gospodarskoj djelatnosti samo u slučaju usluga koje se uobičajeno pružaju uz određenu naknadu, pri čemu naknada predstavlja ekonomsku protučinidbu za uslugu koja se pruža. S druge strane, uspostavljajući i održavajući sustav javnog obrazovanja, koji se u pravilu financira iz javnog

14 Vidi spojene predmete C-180/98 do C-184/98 Pavel Pavlov and Others v Stichting Pensioenfonds Medische Specialisten [2000.], ECR I-6451, točka 76. U ovom kontekstu i povijesni kriterij može biti od važnosti. Vidi predmet C-475/99 Ambulanz Glöckner v Landkreis Südwestpfalz [2001.], ECR I-8089, točka 20. U navedenom je predmetu privatni pravni subjekt pružao uslugu hitnog prijevoza za zdravstvene potrebe. Navedenom subjektu, na temelju novih državnih propisa, odbijeno je produljenje dozvole na koji način je javnim poduzetnicima dodijeljeno isključivo pravo pružanja navedene usluge. Ovdje se pokazalo bitnim to što su u pružanju usluge prethodno sudjelovali privatni subjekti, što je značilo da nije riječ o djelatnosti koju nužno obavljaju subjekti kojima su dana isključiva ili posebna prava. Iz navedenog razloga subjekti kojima su dana isključiva prava obavljanja usluge bili su poduzetnici u smislu prava EU-a. 
proračuna, a ne iz sredstava plaćenih od strane učenika ili njihovih roditelja, država nema namjeru izvršavati djelatnosti uz naknadu, već ispunjava zadaću koju ima prema svojem stanovništvu u socijalnom, kulturnom i obrazovnom području. Iz navedenog razloga Belgija je imala pravo naplaćivati državljanima drugih država članica višu školarinu nego svojim vlastitim državljanima. ${ }^{15}$

U spomenutom predmetu nije jasno riješeno pitanje obrazovanja koje pružaju subjekti u privatnom vlasništvu koji se pretežno financiraju kroz školarine, kao ni visokog obrazovanja. Presudom u predmetu Wirth Sud Europske unije utvrdio je da tečajevi koje pružaju obrazovne ustanove, a financiraju se privatnim sredstvima koja ne potječu od samog pružatelja usluga, predstavljaju usluge s obzirom na to da je cilj spomenutih ustanova ponuditi uslugu uz naknadu i ostvariti dobit. ${ }^{16}$ U ovom kontekstu nije potrebno da navedeno financiranje osiguraju uglavnom sami učenici ili njihovi roditelji jer gospodarska narav određene djelatnosti ne ovisi o tome plaćaju li neku uslugu oni koji se tom uslugom koriste. ${ }^{17}$

Navedena sudska praksa odgovorila je na neka pitanja, no neka je ostavila otvorenima. Prvo pitanje tiče se važnosti stjecanja dobiti kao kriterija za primjenu tržišnih pravila EU-a. U kasnijem predmetu Jundt Sud je, na tu temu, jasno ustvrdio da i subjekti koji ne streme ostvarivanju dobiti mogu obavljati gospodarsku djelatnost pružanjem usluga. ${ }^{18}$ Drugo, mnoge obrazovne ustanove financiraju se iz različitih izvora, od kojih su samo dio privatna sredstva, dok dio dolazi iz javnih izvora. Čak se i pojedini studijski programi mogu istovremeno financirati iz različitih izvora. Ako se ovome nadoda prije opisana sudska praksa koja se tiče definicije poduzetnika, jasno je da je u pojedinom slučaju vrlo teško utvrditi je li riječ o gospodarskoj djelatnosti na koju se primjenjuju tržišna pravila Europske unije ili nije. To je posebno komplicirano utvrditi u slučaju vjerskih zajednica, koje se u različitim državama financiraju iz različitih izvora,

15 Vidi predmet 263/86 Belgian State v René Humbel and Marie-Thérèse Edel [1988.], ECR 5365, točke 14 - 20. Vidi i Hatzopoulos, V., Killing National Health and Insurance Systems but healing Patients? The European Market for Health Care Services after the Judgements of the ECJ in Vanbraekel and Peerbooms, Common Market Law Review, vol. 39, br. 4, 2002., str. 683 - 729. Općenito, o pravu na prekogranični pristup obrazovanju, vidi Jørgensen, S., The Right to Cross-Border Education in the European Union, Common Market Law Review, vol. 46, br. 5, 2009., str. 1567 - 1590.

16 Vidi predmet C-109/92 Stephan Max Wirth v Landeshauptstadt Hannover [1993.], ECR I-6447, točke $13-20$.

17 Vidi predmet C-76/05 Herbert Schwarz and Marga Gootjes-Schwarz v Finanzamt Bergisch Gladbach [2007.], ECR I-6849, točka 41.

18 Vidi predmet C-281/06 Hans-Dieter Jundt and Hedwig Jundt v Finanzamt Offenburg [2007.], ECR I-12231, točka 33. 
na temelju različitih pravnih osnova, i obavljaju širok dijapazon djelatnosti, od kojih se neke očito mogu smatrati gospodarskima, a neke ne.

\subsection{Vjerska zajednica kao poduzetnik}

Pitanje primjene do sada opisanih načela i tumačenja pojavilo se u predmetu Congregación de Escuelas Pías Provincia Betania. Dana 4. ožujka 2011. crkvena zajednica, upisana u evidenciju vjerskih tijela koju vodi španjolsko ministarstvo pravosuđa (Katolička Crkva), zatražila je dozvolu za proširenje i obnovu zgrade u kojoj se nalazi konferencijska dvorana škole "La Inmaculada", kojom ta zajednica upravlja. Navedena dvorana namijenjena je, među ostalim, održavanju tečajeva, sastanaka i konferencija. Dozvola je dodijeljena 8. travnja 2011., pri čemu je spomenuta crkvena zajednica platila općinski porez na građevinske radove (ICIO) u iznosu od 23.730,4l eura. Ona je nakon toga podnijela zahtjev za povrat plaćenog poreza, na temelju Sporazuma o gospodarskim pitanjima (Sporazum) koji je sklopljen 3. siječnja 1979. između Španjolske i Svete Stolice. Navedeni Sporazum propisuje da Crkva ima pravo na trajno i potpuno izuzeće od realnih poreza ili poreza na proizvodnju, koji se odnose na imovinu i prihod. Izuzeće se ne odnosi na prihode od gospodarskih djelatnosti ili upravljanja imovinom Crkve kad je ono prepušteno trećim osobama, na prihode zadržane na izvoru s naslova poreza na dohodak ili na kapitalne dobitke. ${ }^{19}$

Porezni ured odbio je zahtjev Katoličke Crkve jer je ocijenio da se izuzeće iz Sporazuma ne može primijeniti na djelatnost koja nema vjersku svrhu. Katolička Crkva osporila je odluku poreznog ureda (potvrđenu na drugom stupnju) tužbom podnesenom pred nadležnim španjolskim sudom na temelju tumačenja da se izuzeće iz Sporazuma primjenjuje neovisno o namjeni nekretnine koja predstavlja poreznu osnovicu spomenutog poreza. U takvoj situaciji nadležni Pokrajinski upravni sud br. 4 u Madridu prekinuo je postupak i uputio Sudu Europske unije prethodno pitanje protivi li se članku 107. Ugovora o funkcioniranju Europske unije izuzeće Katoličke Crkve od plaćanja poreza u vezi s radovima na nekretninama koje su namijenjene izvršavanju gospodarskih djelatnosti koje nemaju (isključivo) vjersku svrhu. ${ }^{20}$

U presudi je Sud ukratko rekapitulirao svoju dosadašnju praksu. Naveo je da su poduzetnici svi subjekti koji se bave nekom gospodarskom djelatnošću, neovisno o pravnom statusu navedenih subjekata i načinu njihova financira-

19 Vidi predmet C-74/16 Congregación de Escuelas Pías Provincia Betania v Ayuntamiento de Getafe (27. lipnja 2017.), točke 1 - 15.

Vidi ibid., točke $16-21$. 
nja. Gospodarska je djelatnost, prema Sudu, svaka djelatnost koja se sastoji od ponude usluge ili robe na tržištu, bez obzira na postojanje ili nepostojanje namjere stjecanja dobiti, s obzirom na to da spomenuta ponuda u svakom slučaju konkurira ponudi subjekata čiji cilj jest stjecanje dobiti. Usluge se smatraju gospodarskom djelatnošću u slučaju postojanja protučinidbe za njihovo pružanje. Ona ne postoji ako je riječ o ustanovama koje su sastavni dio javnog obrazovnog sustava te se pretežno ili u cijelosti financiraju iz javnih izvora, a postoji u slučaju tečajeva koji se financiraju privatno, iz izvora koji ne potječu od pružatelja usluge, odnosno države. Naravno, neka ustanova može istodobno obavljati više djelatnosti, od kojih su samo neke gospodarske. U tom slučaju mora se voditi odvojeno računovodstvo za financijska sredstva koja potječu iz različitih izvora kako bi se izbjeglo "križno" subvencioniranje gospodarskih djelatnosti subjekta javnim sredstvima koja taj subjekt koristi na temelju vlastitih negospodarskih djelatnosti. ${ }^{21}$

Nakon rekapitulacije vlastite prakse Sud se pozabavio konkretnim slučajem. Prvo je utvrdio da Katolička Crkva u okviru škole obavlja vjersku djelatnost, pruža obrazovne usluge koje dijelom financira španjolska država, kao i one koje ne financira država, uz dodatne usluge prijevoza i prehrane učenika. Sama dvorana za koju se tražilo porezno izuzeće služi samo za pružanje obrazovnih usluga - onih financiranih iz javnih sredstava i onih koje se financiraju iz drugih (privatnih) izvora. Potonje djelatnosti koje organizira Katolička Crkva, a financiraju se pretežno privatnim doprinosima učenika i njihovih roditelja, predstavljaju gospodarske djelatnosti na koje se primjenjuju pravila EU-a o državnim potporama. Takve potpore mogu biti zabranjene ako su zadovoljeni svi uvjeti propisani Ugovorom o funkcioniranju Europske unije. Što se tiče samo konferencijske dvorane, ako služi isključivo za obavljanje obrazovne djelatnosti koju financira španjolska država, porezno izuzeće ne može biti obuhvaćeno zabranom državnih potpora predviđenom pravom EU-a. Porezno izuzeće će, pak, biti obuhvaćeno navedenom zabranom ako se konferencijska dvorana koristi i za djelatnosti koje ne financira država. Drugim riječima, za primjenu pravila EU-a o državnim potporama dovoljno je da samo jedan dio djelatnosti koje se obavljaju u dvorani nije subvencioniran od strane države. U takvom slučaju Katolička Crkva smatra se poduzetnikom i porezno izuzeće može biti nespojivo s pravilima o zabranjenim državnim potporama na unutarnjem tržištu, ako se zadovolje preostali propisani uvjeti koji nisu predmet ovog članka. ${ }^{22}$

21 Ibid., i točke $41-51$.

22 Ibid., točke $52-64$. 
Analizirana presuda ostavila je više neodgovorenih pitanja. Prvo, koliki je postotak djelatnosti koje obavlja određena vjerska zajednica potreban da bi se primijenila pravila o državnim potporama? Hipotetski, ako se dvorana $95 \%$ vremena koristi za obavljanje negospodarske obrazovne djelatnosti koju financira država, hoće li onih preostalih 5 \% vremena biti dovoljno za primjenu pravila o državnim potporama? Ako je odgovor potvrdan (a čini se da jest), postavlja se drugo pitanje: Može li vjerska zajednica biti izuzeta od plaćanja poreza u razmjernom dijelu, odnosno onom dijelu koji se odnosi na obavljanje negospodarske djelatnosti? U hipotetskom primjeru to bi značilo da bi vjerska zajednica morala platiti samo $5 \%$ predmetnog poreza na građevinske radove. Iz odluke Suda nije posve jasan odgovor na to pitanje. Također, čini se da je Sud u području obrazovanja primijenio jednostavniji pristup (temeljen na izvoru financiranja) nego u ostalim područjima, što dovodi do pitanja usklađenosti sudske prakse u tim različitim sferama. ${ }^{23} \mathrm{Na}$ kraju, postavlja se općenito pitanje odnosa između međunarodnih ugovora koje su sklopile države članice sa Svetom Stolicom i tržišnih propisa EU-a, što će biti detaljnije analizirano u idućim poglavljima, $u$ kontekstu pravnog uređenja Republike Hrvatske.

\section{PRAVNI POLOŽAJ KATOLIČKE CRIVVE U REPUBLICI HRVATSKOJ}

\subsection{Važeći pravni okvir}

Kako bi bilo moguće analizirati pravni položaj Katoličke Crkve u Republici Hrvatskoj, nužno je uzeti u obzir niz elemenata. Ponajprije, treba imati na umu odredbu čl. 141. Ustava ${ }^{24}$ Republike Hrvatske (dalje u tekstu: Ustav) ${ }^{25}$, koja glasi:

"Međunarodni ugovori koji su sklopljeni i potvrđeni u skladu s Ustavom i objavljeni, a koji su na snazi, čine dio unutarnjega pravnog poretka Republike Hrvatske, a po pravnoj su snazi iznad zakona. Njihove se odredbe mogu mijenjati ili ukidati samo uz uvjete i na način koji su u njima utvrđeni, ili suglasno općim pravilima međunarodnog prava."

23 Vidi i Kloosterhuis, E., Defining non-economic activities in competition law, European Competition Journal, vol. 13, br. 1, 2017., str. 117 - 149.

Čl. 134. prema redakcijski uređenom tekstu Ustava Ustavnog suda Republike Hrvatske, nap. a.

25 Narodne novine, br. 56/1990, 135/1997, 113/2000, 28/2001, 76/2010, 85/2010 pročišćeni tekst i 5/2014. 
Dodatno, a u kontekstu ovog rada, treba imati na umu i odredbu čl. 145. Ustava $^{26}$, koja glasi:

"Ostvarivanje prava koja proizlaze iz pravne stečevine Europske unije, izjednačeno je s ostvarivanjem prava koja su zajamčena hrvatskim pravnim poretkom.

Pravni akti i odluke koje je Republika Hrvatska prihvatila u institucijama Europske unije primjenjuju se u Republici Hrvatskoj u skladu s pravnom stečevinom Europske unije.

Hrvatski sudovi štite subjektivna prava utemeljena na pravnoj stečevini Europske unije.

Državna tijela, tijela jedinica lokalne i područne (regionalne) samouprave te pravne osobe s javnim ovlastima izravno primjenjuju pravo Europske unije."

Ta odredba zapravo znači ustavno prihvaćanje primata prava Europske unije nad ostalim izvorima prava u Republici Hrvatskoj, a sukladno doktrini o primatu prava Europske unije koja je izvorno formulirana u praksi Europskog suda, posebice u predmetima Van Gend en $\operatorname{Loos}^{27}$, Costa v. ENEL ${ }^{28}$ te Simmenthal $2^{29}$.

Treba na ovom mjestu naglasiti i postojanje čl. 351. st. l. Ugovora o funkcioniranju Europske unije koji “suspendira načelo primata dozvoljavajući državama članicama da primjenjuju ugovore s trećim državama, sklopljene prije pristupanja, unatoč suprotnim obvezama prema pravu EU". ${ }^{30}$ Međutim, iz st. 2. istog članka Ugovora o funkcioniranju Europske unije proizlazi obveza za države članice da eliminiraju takve nekompatibilnosti, s obzirom na to da čl. 35l. ne stvara generalnu derogaciju načela primata. ${ }^{31}$ Treba dodatno naglasiti da se obveza iz čl. 351. st. 2. primjenjuje isključivo ako se utvrdi da je nekompatibilnost dovoljno

26 Čl. 14l.c prema redakcijski uređenom tekstu Ustava Ustavnog suda Republike Hrvatske, nap. a.

27 Predmet C-26/62 Van Gend en Loos v. Nederlandse Administratie des Belastigen.

28 Predmet C-6/64 Costa v ENEL.

29 Predmet C-106/77 Amministrazione delle Finanze v. Simmenthal SpA.

30 Stirk, P., Shaping the Single European Market in the Field of Foreign Direct Investment, Hart Publishing, 2016., str. 154.

31 Ibid. Stajalište da čl. 351. st. 1. Ugovora o funkcioniranju Europske unije upravo predstavlja ponajprije iznimku od načela primata prava EU-a, vidi u: Papp, K., Solving Conflicts with International Investment Treaty Law from an EU Law Perspective: Article 351 TFEU Revisited, http://eprints.keele.ac.uk/3541/1/K\%20von\%20Papp\%20-\%20 Solving\%20Conflicts\%20with\%20International\%20Investment\%20Treat $\% 20$ Law\%20from\%20an\%20EU\%20Law\%20Perspective.pdf (29. siječnja 2018.). 
jasno utvrđena. ${ }^{32}$ Prema tome, ne primjenjuje se automatski. Dodatno, očita je tenzija između pravnih posljedica propisanih st. 1. čl. 35l. (raniji ugovori ostaju obvezujući) i pravnih posljedica propisanih st. 2. čl. 351. (nekompatibilnosti u tim ranijim ugovorima s pravom EU-a ne mogu opstati). ${ }^{33}$ Prema tome, a sukladno praksi Suda EU-a, važenje ranijih ugovora čije se odredbe kose s pravom EU-a je privremeno ${ }^{34}$, ali samo ako se utvrdi jasna nekompatibilnost.

Ipak, treba naglasiti da je, sukladno praksi Ustavnog suda Republike Hrvatske (dalje u tekstu: Ustavni sud) u Republici Hrvatskoj uistinu na snazi načelo primata prava Europske unije, ali ne u smislu nadređenosti cijelom nacionalnom pravnom sustavu, s obzirom na to da je Ustav nadređen pravu Europske unije. To stajalište Ustavni sud zauzeo je u odluci U-VIIR-1159/2015 od 8. travnja 2015. godine ${ }^{35}$ kada je istaknuo sljedeće:

"Ustavni sud na kraju ocjenjuje da u ovom ustavnosudskom postupku nije potrebno ispitivati materijalnopravnu suglasnost referendumskog pitanja $s$ pravom Europske unije jer je Ustav po svojoj pravnoj snazi iznad prava Europske unije [istaknuli autori]. Drugim riječima, s obzirom na točke I. i II. izreke ove odluke, ne postoje razlozi da se ispitivanje provede is aspekta prava koje u Republici Hrvatskoj važi na temelju osnivačkih ugovora u svjetlu članka 141.c Ustava."

Sukladno navedenim odredbama Ustava i citiranoj praksi Ustavnog suda, u hrvatskom pravnom poretku utvrđena je hijerarhija pravnih normi na sljedeći način:

I. Ustav

2. norme europskog prava

3. međunarodni ugovori

4. zakon

5. podzakonski propisi.

Jednako tako, treba posebno istaknuti odredbe čl. 40. i čl. 4l. Ustava koje glase:

"Jamči se sloboda savjesti i vjeroispovijedi i slobodno javno očitovanje vjere ili drugog uvjerenja."

Vidi predmet C-203/03 Commission v Luxembourg [2005.], ECR I-935, točka 62.

33 Papp, op. cit. u bilj. 31, str. 9.

34 Vidi predmet C-205/06 Commission v Republic of Austria [2009.], ECR I-1301, i predmet C-249/06 Commission v Kingdom of Sweden, ECR I-1335.

35 Narodne novine, br. 43/2015. 
"Sve vjerske zajednice jednake su pred zakonom i odvojene od države.

Vjerske zajednice slobodne su, u skladu sa zakonom, javno obavljati vjerske obrede, osnivati škole, učilišta, druge zavode, socijalne i dobrotvorne ustanove te upravljati njima, a u svojoj djelatnosti uživaju zaštitu i pomoć države."

Navedene odredbe uspostavile su pravo slobode vjeroispovijesti, ali i uspostavile okvir za odnos crkve i države u Republici Hrvatskoj. Naime, sukladno uvriježenoj podjeli, može se reći da su se u teoriji (a i u praksi) iskristalizirala tri opća modela odnosa crkve i države:

1. model državnih ili nacionalnih crkava

2. kooperacijski ili konkordatski model

3. model striktne odvojenosti crkve i države (separacijski model). ${ }^{36}$

Kada analiziramo odredbu čl. 41. Ustava, vidimo da su u Republici Hrvatskoj crkva i država odvojene, ali jednako tako vidimo da je odredbom čl. 41 . st. 2. Ustava uspostavljena dužnost i obveza države da štiti vjerske zajednice i pomaže im u njihovoj djelatnosti. Prema tome, u Republici Hrvatskoj je na snazi kooperacijski ili konkordatski model odnosa crkve i države. U vezi s načinom na koji treba tumačiti odredbu čl. 41. st. l. Ustava "i odvojene od države" kao ilustrativno može nam poslužiti rješenje Ustavnog suda Republike Hrvatske U-II/2050/2012 od 13. studenog 2012. ${ }^{37}$ kojim je Ustavni sud odbio prijedlog za pokretanje postupka za ocjenu suglasnosti s Ustavom čl. 163. Uredbe o unutarnjem ustrojstvu Ministarstva obrane. Tom je odredbom uspostavljen Samostalni odjel za potporu Vojnom ordinarijatu u Republici Hrvatskoj (Vojni ordinarijat) unutar Ministarstva obrane Republike Hrvatske. Osporena je iz razloga nesukladnosti s čl. 4l. st. 1. Ustava. Ustavni sud prijedlog je odbio i uspostavio "odvojenost" iz čl. 4l. st. l. Ustava kao dvosmjernu barijeru. Ona

36 Zrinščak, S., Religija i društvo, u: Kregar, J. et al., Uvod u sociologiju, Pravni fakultet u Zagrebu, Zagreb, 2014., str. 505. Ti se modeli dalje mogu razraditi. Primjerice, na šest modela odnosa između crkve i države: 1) agresivni animozitet između crkve i države (komunistički režimi), 2) stroga razdvojenost u teoriji i praksi (Francuska), 3) stroga odvojenost u teoriji, ali ne i u praksi (SAD), 4) odvojenost i suradnja (SR Njemačka), 5) formalno jedinstvo, ali sa supstancijalnom podjelom (UK, Danska, Izrael, Norveška) i 6) formalno i supstancijalno jedinstvo (IR Iran, Saudijska Arabija - gdje je, dakako, riječ o supstancijalnom jedinstvu odnosnih islamskih zajednica i države)). Navedenu razradu na šest modela vidi u: Brugger. V., On the Relationship between Structural Norms and Constitutional rights in Church-State-Relations, u: Brugger, W., Karayanni, M. (ur.), Religion in the Public Sphere: A Comparative Analysis of German, Israeli, American and International Law, Springer, Berlin - Heidelberg - New York, 2007., str. 31.

37 Dostupno na www.usud.hr (7. prosinca 2017.). 
čuva autonomnost vjerske zajednice od presezanja države, ali ima zadatak i spriječiti upletanje religijskih organizacija u državne poslove. ${ }^{38}$

Općenito govoreći, položaj vjerskih zajednica u Republici Hrvatskoj uređen je Zakonom o pravnom položaju vjerskih zajednica iz 2002. godine, koji propisuje pravni status vjerskih zajednica te ih, u osnovi, dijeli u dvije velike skupine ${ }^{39}$ : registrirane vjerske zajednice koje su sklopile ${ }^{40}$ ugovore s državom o pitanjima

38 Miloš, M., Hrvatske vjerske zajednice u (protu) većinskoj prizmi svjetovne države, Zbornik Pravnog fakulteta Sveučilišta u Rijeci, vol. 35, 2014., br. 2, str. 660.

39 Zapravo se vjerske zajednice u Republici Hrvatskoj mogu podijeliti na pet tipova:

1. Katolička Crkva, čiji je položaj reguliran međunarodnim ugovorima i koja ima specijalni, sui generis status unutar hrvatskog pravnog sustava i na koju se, u najvećoj mjeri, ne primjenjuje ZPVZ

2. vjerske zajednice koje su potpisale posebne ugovore s državom

3. registrirane vjerske zajednice

4. neregistrirane vjerske zajednice koje imaju pravni oblik vjerskih udruga, tzv. vjerske zajednice u nastajanju

5. neregistrirane vjerske zajednice koje nemaju ni pravni oblik vjerskih udruga.

Vidi u: Staničić, F., The Legal Status of Religious Communities in Croatian Law, Zbornik Pravnog fakulteta u Zagrebu, vol. 64., br. 2, 2014., str. 244.

40 Sklopljeno je osam ugovora s ukupno 19 vjerskih zajednica:

1. 20. prosinca 2002. godine sa Srpskom pravoslavnom crkvom (Narodne novine, br. 196/2003)

2. 20. prosinca 2002. godine s Islamskom zajednicom (Narodne novine, br. $196 / 2003$ i 86/2014 - ispravak)

3. 4. srpnja 2003. godine s Evangeličkom crkvom u Republici Hrvatskoj i Reformiranom kršćanskom (kalvinskom) crkvom u Hrvatskoj (Narodne novine, br. 196/2003)

4. 4. srpnja 2003. godine s Evanđeoskom pentekostnom crkvom u Republici Hrvatskoj (koja zastupa još dvije crkve: Crkvu Božju u Republici Hrvatskoj i Savez Kristovih pentekostnih crkava u Republici Hrvatskoj), Kršćanskom adventističkom crkvom u Republici Hrvatskoj (koja zastupa još jednu crkvu: Reformni pokret adventista sedmog dana) i Savezom baptističkih crkava u Republici Hrvatskoj (koji zastupa još jednu crkvu: Kristovu crkvu) (Narodne novine, br. 196/2003)

5. 29. listopada 2003. godine s Bugarskom pravoslavnom crkvom u Hrvatskoj, Hrvatskom starokatoličkom crkvom i Makedonskom pravoslavnom crkvom u Hrvatskoj (Narodne novine, br. 196/2003)

6. 6. listopada 2010. godine s Koordinacijom židovskih općina u Republici Hrvatskoj (Narodne novine, br. 4/2012)

7. 27. listopada 2011. godine sa Židovskom vjerskom zajednicom Bet Israel u Hrvatskoj (Narodne novine, br. 4/2012)

8. 12. rujna 2014. godine sa Savezom crkava "Riječ života", Crkvom cjelovitog evanđelja i Protestantskom reformiranom kršćanskom crkvom u Republici Hrvatskoj (Narodne novine, br. 112/2014). 
od zajedničkog interesa (vidi čl. 9. st. l. toga Zakona) i na registrirane vjerske zajednice.

Ipak, položaj Katoličke Crkve u Republici Hrvatskoj poseban je u odnosu na položaj ostalih vjerskih zajednica, možemo reći da je riječ o položaju sui generis. Naime, sukladno citiranoj odredbi čl. 14l. Ustava, Republika Hrvatska i Sveta Stolica sklopili su četiri međunarodna ugovora kojima je, u najvećoj mjeri, uređen pravni položaj Katoličke Crkve u Republici Hrvatskoj. To su:

1. Ugovor o pravnim pitanjima - stupio na snagu 9. travnja 1997. godine ${ }^{41}$

2. Ugovor o dušobrižništvu katoličkih vjernika, pripadnika oružanih snaga i redarstvenih službi Republike Hrvatske - stupio na snagu 9. travnja 1997. godine $^{42}$

3. Ugovor o suradnji na području odgoja i kulture - stupio na snagu 9. travnja 1997. godine ${ }^{43}$

4. Ugovor o gospodarskim pitanjima - stupio na snagu 14. prosinca 1998. $\operatorname{godine}^{44}$.

Sukladno navedenome, može se reći da je, u Republici Hrvatskoj, položaj Katoličke Crkve uređen primarno normama Ustava, zatim četirima međunarodnim ugovorima koje je Republika Hrvatska sklopila sa Svetom Stolicom, a tek podredno odredbama Zakona o položaju vjerskih zajednica i podzakonskim aktima u onom dijelu u kojemu njezin položaj nije uređen spomenutim međunarodnim ugovorima. ${ }^{45}$ Prema tome, odnos Katoličke Crkve i Republike Hrvatske drukčiji je od odnosa Republike Hrvatske sa svim ostalim vjerskim zajednicama koje djeluju na njezinu teritoriju. Takav, poseban odnos, posljedica je posebnog ustrojstva Katoličke Crkve koji joj je omogućio da svoj odnos s Republikom Hrvatskom uredi međunarodnim ugovorima između Republike Hrvatske i Svete Stolice koji su, sukladno našem Ustavu (čl. 141.), po svojoj pravnoj snazi iznad hrvatskih zakona. To znači da Katolička Crkva uživa nadzakonski pravni status u Republici Hrvatskoj i da se na njezin položaj hrvatsko zakonodavstvo primjenjuje isključivo u onim područjima koja nisu uređena spomenutim međunarodnim ugovorima.

Glede mogućnosti promjene citiranih ugovora, oni sadržavaju formulaciju koja je, u gotovo identičnom obliku, sadržana u svim četirima ugovorima između Svete Stolice i Republike Hrvatske:

41 Narodne novine, Međunarodni ugovori, br. 3/1997.

42 Narodne novine, Međunarodni ugovori, br. 2/1997.

43 Narodne novine, Međunarodni ugovori, br. 2/1997.

44 Narodne novine, Međunarodni ugovori, br. 18/1998.

45 Staničić, op. cit. u bilj. 39, str. 246. 
"U slučaju da jedna od visokih ugovornih Strana bude smatrala da su se bitno promijenile prilike u kojima je sklopljen ovaj Ugovor, tako da ga treba mijenjati, započet će odgovarajuće pregovore."

Iz toga slijedi da se ugovori između Svete Stolice i Republike Hrvatske ne mogu jednostrano mijenjati. Izmjene ugovora moguće su isključivo na temelju dogovora obiju strana. Upitna je mogućnost tumačenja pojedinih ugovornih odredbi putem Međunarodnog suda (ICJ). Naime, stranke moraju pristati na njegovu nadležnost, a treba imati u vidu okolnost da jedna stranka nije država članica Ujedinjenih naroda i predstavlja iznimno specifičan subjekt međunarodnog prava. ${ }^{46}$ Ta okolnost proizlazi iz činjenice da, prema dostupnim podacima, Sveta Stolica odnosno Država Vatikanskog Grada i Republika Hrvatska nisu kod glavnog tajnika Ujedinjenih naroda deponirale potrebnu izjavu iz čl. 36. Statuta Međunarodnog suda. ${ }^{47}$ Prema tome, bez dogovora stranaka potpisnica izmjena i/ili raskid ugovora nije, pravno gledano, moguć.

\subsection{Pravni položaj Katoličke Crkve u Republici Hrvatskoj}

Za potrebe ovoga rada od spomenutih četiriju ugovora između Republike Hrvatske i Svete Stolice posebno su važna dva: Ugovor o pravnim pitanjima i Ugovor o gospodarskim pitanjima. Naime, tim je ugovorima postavljen javnopravni status Katoličke Crkve, kao i niz pitanja koja se tiču gospodarskih odnosa između države i Katoličke Crkve.

\subsubsection{Ugovor o pravnim pitanjima}

Taj ugovor, s pravnog gledišta, najvažniji je od četiriju ugovora jer je u njemu, kako se navodi u literaturi ${ }^{48}$, uređen gotovo cjeloviti "pravni okvir" odnosa Republike Hrvatske i Katoličke Crkve. ${ }^{49}$ Sukladno tome ugovoru, Republika Hrvatska priznaje javnu pravnu osobnost Katoličke Crkve, kao i javnu pravnu osobnost

46 Babić, M., Kunštek, E., Neke dvojbe u primjeni Zakona o naknadi za imovinu oduzetu za vrijeme jugoslavenske komunističke vladavine - Pravna narav roka za pokretanje postupka I odnos prema Ugovoru Republike Hrvatske i Svete Stolice o gospodarskim pitanjima, Zbornik Pravnog fakulteta Sveučilišta u Rijeci, vol. 37, br. 1, 2016., str. 93. kracije, Crkva u svijetu, vol. 50, br. 3, 2015, str. 497.

49 
svih crkvenih ustanova, koje imaju takvu pravnu osobnost prema odredbama kanonskoga prava. Crkvene pravne osobe mogu kupovati, posjedovati, koristiti ili otuđivati pokretna i nepokretna dobra te stjecati i otuđivati imovinska prava, prema odredbama kanonskoga prava i zakonodavstva Republike Hrvatske. Ugovorom je uspostavljena potpuna autonomija Katoličke Crkve pri osnivanju, mijenjanju itd. crkvenih pravnih osoba. Naime, nadležna crkvena vlast može osnivati, mijenjati, dokidati ili priznavati crkvene pravne osobe, prema odredbama kanonskoga prava. Ona o tome obavještava nadležno tijelo državne uprave zbog njihova upisa, u skladu s odgovarajućim državnim propisima. Na temelju čl. 2. Ugovora o pravnim pitanjima Vlada Republike Hrvatske i Hrvatska biskupska konferencija potpisale su 12. rujna 2002. Protokol o načinu upisa pravnih osoba Katoličke Crkve u evidenciju ministarstva nadležnog za poslove opće uprave. ${ }^{50}$ Crkvene ustanove za karitativno djelovanje i društvenu skrb ili ustanove koje ovise o Katoličkoj Crkvi djeluju prema vlastitim statutima, ali se moraju ravnati prema odredbama hrvatskog zakonodavstva te imaju ista prava i povlastice koje imaju i državne ustanove osnovane $\mathrm{u}$ istu svrhu.$^{51}$ Republika Hrvatska zajamčila

50 Narodne novine, Međunarodni ugovori, br. 15/2003 i 16/2003.

51 Javlja se pitanje potrebe registracije pravnih osoba Katoličke Crkve kao, primjerice, udruga, ako im je već, prema odredbama kanonskog prava, priznata pravna osobnost, a onda, posljedično, i pravna osobnost prema propisima RH. Smatramo da je, unatoč tome što takve ustanove Katoličke Crkve već imaju pravnu osobnost, potrebno provesti njihovu registraciju kao udruge ako želi djelovati kao udruga s pravnom osobnošću. Naime, istina je da je pravnim osobama Katoličke Crkve priznata pravna osobnost, te, posljedično, mogu biti nosioci prava i obveza (čl. 10. Ugovora), ali kakve su one pravne osobe? Je li riječ o ustanovama, trgovačkim društvima ili pravnim osobama sui generis? Analizirajući posebno odredbu čl. 14. st. 1. Ugovora, kao i njegove druge relevantne odredbe, zaključujemo da je, u slučaju da pravne osobe Katoličke Crkve žele djelovati u pravnom sustavu Republike Hrvatske kao određena vrsta pravne osobe, nužna registracija tih pravnih osoba na odgovarajući način, ovisno o djelatnosti kojom se žele baviti. Ako je riječ o ustanovi, koja primjerice obavlja djelatnosti obrazovanja (školstva), mora se upisati u sudski registar, a ako žele djelovati kao udruge, posebno ako žele dotaciju iz državnog proračuna, moraju se upisati u registar udruga na za to ZU-om predviđen način. To se posebno odnosi na vjernička društva, bilo privatna bilo javna, koja bi eventualno htjela djelovati i izvan odredaba kanonskog prava. Vidi u: Staničić, F., Ofak, L., Registracija vjerskih zajednica $i$ vjerskih udruga u svjetlu Europske konvencije za zaštitu ljudskih prava $i$ temeljnih sloboda, u: Šalković, J. (ur.), Vjernici, društva i pokreti, Glas koncila, Zagreb, 2011., str. 231.

Mora se istaknuti da je moguće, na temelju Ugovora o pravnim pitanjima, zauzeti i suprotno mišljenje, odnosno da je moguće ustvrditi da bi se prihvaćanjem gore navedenog stava jednostrano od strane države nametala ponovna obveza konstitutivne registracije koja je već, po kanonskom pravu, obavljena i, sukladno Ugovoru 
je Katoličkoj Crkvi slobodu obavljanja bogoštovlja, kao i nepovredivost mjesta za bogoštovlje, a također je utvrđena isključiva nadležnost Katoličke Crkve za sva crkvena imenovanja i dodjelu crkvenih službij ${ }^{52}$, prema odredbama kanonskoga prava. Utvrđeni su i neradni dani (nedjelje i crkveni blagdani). Katoličkoj je Crkvi "zajamčena sloboda tiska", a to se odnosi na tiskanje i širenje knjiga, novina, časopisa te drugih djelatnosti iz djelokruga izdavaštva koje su povezane s poslanjem Crkve. Kako bi se stvorili uvjeti za primjenu dijela Ugovora o sklapanju kanonskih ženidaba s građanskim učincima, promijenjen je Obiteljski zakon, koji propisuje da se brak u vjerskom obliku s učincima građanskog braka sklapa pred službenikom vjerske zajednice koja s Republikom Hrvatskom o tome ima uređene odnose, a Ministarstvo uprave propisalo je oblik Potvrde o ispunjenju pretpostavki za sklapanje braka u vjerskom obliku. ${ }^{53}$ Republika Hrvatska priznala je i zajamčila Katoličkoj Crkvi pravo na dušobrižništvo vjernika koji se nalaze u zatvorima, bolnicama, lječilištima, sirotištima i svim ustanovama za zdravstvenu i društvenu skrb, bilo da su javnoga bilo privatnog značenja, o čemu se trebao sklopiti posebni ugovor između nadležnih crkvenih vlasti i tijela Republike Hrvatske. Vlada Republike Hrvatske i Hrvatska biskupska konferencija potpisale su na temelju te ugovorne odredbe dva dokumenta: Sporazum o dušobrižništvu u kaznionicama, zatvorima i odgojnim zavodima 2002. godine i Ugovor o dušobrižništvu u bolnicama i ostalim zdravstvenim ustanovama te ustanovama socijalne skrbi 2005. godine. ${ }^{54}$

o pravnim pitanjima, automatski prihvaćena od strane države. Naime, moguće je smatrati da je, uspostavljanjem posebnog registra crkvenih pravnih osoba (Evidencija pravnih osoba Katoličke Crkve u Republici Hrvatskoj), država pristala na priznavanje pravne osobnosti pravnih osoba Katoličke Crkve, bez potrebe posebne registracije u za to predviđenim državnim registrima. Treba također naglasiti da bi potreba "dodatne" registracije u državnim registrima mogla stvoriti određenu pravnu nesigurnost jer bi postojala dva konstitutivna akta i datuma o osnivanju iste pravne osobe (kanonski i državnopravni).

Svakako je riječ o problemu koji bi trebalo riješiti, a mogući način jest sklapanje posebnog ugovora između Hrvatske biskupske konferencije i Vlade Republike Hrvatske o registraciji crkvenih pravnih osoba u odgovarajućim registrima i načinu provođenja takve registracije.

52 Kao zanimljivost ističemo odredbu dužnosti sudskih vlasti da, u slučaju sudske istrage o kleriku zbog možebitnih kaznenih djela predviđenih kaznenim zakonom, o tome prethodno obavijeste nadležne crkvene vlasti.

Jakulj, op. cit. u bilj. 48, str. 501.

Ibid., str. 502. 


\subsubsection{Ugovor o gospodarskim pitanjima}

Ugovor između Svete Stolice i Republike Hrvatske o gospodarskom pitanjima ima 15 članaka i u njemu su ugovorne strane dogovorile: 1. pitanje slobodnog davanja milostinja i drugih darova vjernika Katoličkoj Crkvi; 2. pitanja povrata oduzete imovine i načina naknade za nju; 3. način financiranja Katoličke Crkve; 4. pitanje mirovina svećenika, redovnika i redovnica te 5) način zajedničkog rada Crkve i države na planu općeg dobra. ${ }^{55}$ Republika Hrvatska se obvezala da će Katoličkoj Crkvi a) vratiti imovinu što joj je oduzeta u vrijeme jugoslavenske komunističke vladavine, a koju je moguće vratiti prema zakonskim odredbama, b) naći odgovarajuću zamjenu za dio dobara koja nije moguće vratiti ili c) isplaćivati pravnim osobama Katoličke Crkve naknadu u novcu za ostalu imovinu koja neće biti vraćena.

Dodatno, država se obvezala, zbog priznavanja njezina opće društveno vrijednog rada na kulturnom, odgojnom, društvenom i etičkom polju, Katoličkoj Crkvi osiguravati određen godišnji novčani iznos. U novčani iznos koji Republika Hrvatska isplaćuje Katoličkoj Crkvi, osim troškova za uzdržavanje klera i drugih crkvenih službenika ${ }^{56}$, uključeni su i troškovi izgradnje i uzdržavanje crkava i pastoralnih središta koji nisu na popisu spomenika kulture te doprinos za karitativnu djelatnost ${ }^{57}$ Katoličke Crkve.

Dodatno financijsko opterećenje koje za državu proizlazi iz Ugovora o gospodarskim pitanjima propisano je u odredbi da će na preporuku dijecezanskog biskupa državne vlasti svake godine razmatrati, odobriti i financijski pomagati posebne programe i projekte pravnih osoba Katoličke Crkve koji su korisni za opće dobro.

Glede poreznog statusa Katoličke Crkve, Ugovorom o gospodarskim pitanjima propisano je da pravne osobe Katoličke Crkve, u skladu s odredbama kanonskog prava, mogu slobodno primati milostinju i darove vjernika te prihvaćati druge uobičajene oblike prinosa vjernika za uzdržavanje crkvenih ustanova te se na ta primanja ne primjenjuju odredbe poreznoga sustava Republike Hrvatske. Dodatno, propisano je da se pravne osobe Katoličke Crkve u odnosu na porezni sustav smatraju neprofitnim ustanovama, što ne vrijedi za njihove profitne

55 Ibid., str. 504 i 505.

56 Republika Hrvatska Katoličkoj Crkvi mjesečno daje iz godišnjega državnoga proračuna iznos koji odgovara dvjema prosječnim bruto plaćama pomnoženim s brojem župa koje postoje u Republici Hrvatskoj na dan stupanja na snagu Ugovora o gospodarskim pitanjima.

57 Na taj način izvršena je obveza glede financiranja karitativnih ustanova Katoličke Crkve koja je proizlazila iz Ugovora o pravnim pitanjima, nap. a. 
djelatnosti. Slične se odredbe nalaze u konkordatima i Ugovorima Svete Stolice sa Španjolskom, Italijom, Poljskom te četirima saveznim zemljama Savezne Republike Njemačke. ${ }^{58}$

Pažljivim čitanjem Ugovora o gospodarskim pitanjima vidimo da iz njega proizlazi da sve djelatnosti koje proizlaze iz kanonskog prava spadaju u "unutarnje djelatnosti”. Sve što Katolička Crkva ostvari od doprinosa vjernika, spadalo bi u unutarnje djelatnosti, a ne gospodarske. Katolička Crkva prema odredbama Kanonskog zakonika ima pravo na vlastite izvore prihoda: milostinja dana Crkvi koja je istodobno župna i kaptolska (kan. 510. § 4.), prilozi koji se stavljaju u župnu blagajnu (kann. 531. - 551.), prilozi prigodom podjeljivanja sakramenata (kan. 848.), prilog za misno slavlje (kann. 945. - 958.), prilozi prigodom pogreba (kan. 1181.) itd. ${ }^{59}$ Eterović kao vlastite izvore prihoda Katoličke Crkve navodi vjerničke priloge, u koje spadaju: prigodni darovi za župu, biskupiju, potrebe Crkve ili za posebne namjene - sjemenište, svećenike, misije, dobrotvornost itd. Postoje prilozi za uzdržavanje svećenika, za svetišta; prigodni prilozi s posebnom nakanom ustanovama posvećenoga života, udrugama i drugim ustanovama; ostavštine i uopće darovi. ${ }^{60}$

Prema tome, oporezive bi bile samo djelatnosti koje generiraju komercijalne prihode od vlastite imovine (zakup i najam prostora itd.) i prihode iz dobiti trgovačkih društava. ${ }^{61}$ Ipak, određenu "sivu" zonu predstavljali bi prihodi koji se ostvaruju prodajom vjerskih suvenira. To vrijedi za Katoličku Crkvu i njezine pravne osobe kojima je po Ugovoru o pravnim pitanjima priznata javna pravna osobnost, ali ne vrijedi za sve pravne osobe koje nisu pravne osobe s javnom pravnom osobnošću prema Ugovoru o pravnim pitanjima, odnosno koje prema Zakoniku kanonskog prava nemaju javnu pravnu osobnost (privatne osobe), a koje osnuju Katolička Crkva i njezine pravne osobe koje imaju javnu pravnu osobnost. ${ }^{62}$ Prema Eteroviću ta je odredba o neprofitnom statusu pravnih osoba Katoličke Crkve unesena u Ugovor o gospodarskim pitanjima da bi i crkvene pravne osobe bile oslobođene poreznih opterećenja jednako kao i građanske

58 Šinković, Z., Financiranje vjerskih zajednica (doktorska disertacija), Zagreb, 2015., str. 146.

59 Ibid., str. 279.

60 Eterović, op. cit. u bilj. 49, str. 81.

61 Tako i ibid., str. 447.

${ }^{62} \mathrm{O}$ poreznom statusu Katoličke Crkve vidi više u: Staničić, F., Pitanje povrata imovine oduzete Katoličkoj Crkvi i problema tumačenja Ugovora o pravnim pitanjima između Republike Hrvatske i Svete Stolice - pouke za budućnost u rješavanju odnosa crkve i države, u: Šarčević, E., Bojić, D. (ur.), Sekularnost i religija: BiH i Regija, Fondacija za javno pravo, Sarajevo, 2015., str. 205 - 209. 
neprofitne pravne osobe. Ako pak djelatnost crkvenih pravnih osoba bude usmjerena profitnoj djelatnosti, ravnat će se kao i druge pravne osobe u Republici Hrvatskoj, bez posebnih olakšica. ${ }^{63}$

Na temelju gore navedenog može se zaključiti da su Ugovorom o gospodarskim pitanjima predviđeni različiti izvori financiranja Katoličke Crkve:

1. primanje milostinje i darova koji ne podliježe oporezivanju

2. mjesečna izdvajanja iz godišnjeg državnog proračuna vezana uz promicanje općeg dobra Crkve

3. financiranje posebnih programa i projekata pravnih osoba Katoličke Crkve od strane državne vlasti za opće dobro prema preporuci dijecezanskog biskupa, odnosno mjerodavnih tijela (npr. jedinice lokalne i područne (regionalne) samouprave pridonosit će prema svojim mogućnostima izgradnji i obnovi crkvenih zgrada)

4. vraćanje oduzete imovine za vrijeme jugoslavenske komunističke vladavine odnosno isplaćivanje primjerene novčane naknade za imovinu koja ne može biti vraćena. ${ }^{64}$

Potrebno je naglasiti i odredbe Zakona o porezu na dobit ${ }^{65}$ koje propisuju da vjerske zajednice nisu obveznici poreza na dobit. Jedino ako obavljaju gospodarsku djelatnost, a neoporezivanje te djelatnosti dovelo bi do stjecanja neopravdanih povlastica na tržištu, postoji obveza upisivanja u registar poreznih obveznika; a ako ne podnesu prijavu, to će učiniti Porezna uprava po službenoj dužnosti ili na prijedlog drugih poreznih obveznika ili zainteresirane osobe. ${ }^{66}$ Jasna je intencija tih zakonskih odredaba koje korespondiraju onome utvrđenome Ugovorom o gospodarskim pitanjima - da se osigura povoljniji porezni status vjerskih zajednica, pa onda i Katoličke Crkve, ali ne na način da to dovodi do povreda pravila tržišnog natjecanja ili pravila o državnim potporama. U tom se pogledu kao problematična može navesti odredba Ugovora o gospodarskim pitanjima koja obvezuje državu da na preporuku dijecezanskog biskupa svake godine razmotri, odobri i financijski pomaže posebne programe i projekte pravnih osoba Katoličke Crkve koji su korisni za opće dobro.

Smatramo važnim naglasiti i da je danom ulaska Republike Hrvatske u Europsku uniju prestala vrijediti odredba čl. 17. Zakona o pravnom položaju

63 Eterović, op. cit. u bilj. 49, str. 87.

64 Šinković, op. cit. u bilj. 58, str. 154.

65 Narodne novine, br. 177/2004, 90/2005, 57/2006, 146/2008, 80/2010, 22/2012, 148/2013, 143/2014, 50/2016 i 115/2016.

66 Vidi i mišljenje Porezne uprave Klasa: 410-10/06-01/55 od 12. prosinca 2006. 
vjerskih zajednica o oslobađanju vjerskih zajednica od plaćanja poreza na dodanu vrijednost na predmete koje prima od stranih vjerskih zajednica te drugih stranih pravnih i fizičkih osoba, a vjerskoj zajednici, odnosno njezinim svećenicima i drugim vjerskim službenicima služe za obavljanje vjerskih poslova (čl. 14l. Zakona o porezu na dodanu vrijednost). ${ }^{67}$ Međutim, može se pojaviti pitanje vrijedi li to za Katoličku Crkvu, odnosno je li ulaskom u Europsku uniju nastala jasna nekompatibilnost odredbe Ugovora o gospodarskim pitanjima koja se odnosi na oslobođenje od poreza na, primjerice, darove s pravom EU-a. Kako je već navedeno, sukladno čl. 351. st. 1. Ugovora o funkcioniranju EU-a, međunarodni ugovori sklopljeni prije pristupanja EU-u ostaju na snazi. Prema tome, i dalje postoji oslobođenje Katoličke Crkve od plaćanja PDV-a na njezine negospodarske aktivnosti koje su prikazane ("unutarnje djelatnosti”) s obzirom na to da se međunarodni ugovori ne mogu smatrati raskinutima zbog postojanja suprotne odredbe u pravu EU-a, što proizlazi i iz našeg Ustava, koji propisuje da se odredbe međunarodnih ugovora "mogu mijenjati ili ukidati samo uz uvjete i na način koji su u njima utvrđeni, ili suglasno općim pravilima međunarodnog prava."

Samo ako bi se u propisanom postupku utvrdila jasna nekompatibilnost, Republika Hrvatska morala bi ući u postupak pregovora sa Svetom Stolicom oko eventualne izmjene ugovora, ali koji bi se temeljili na načelu do ut des ${ }^{68}$ te ne bi mogli biti promijenjeni bez dogovora obiju strana, za koje bi vrijeme (pregovora) Ugovor o gospodarskim pitanjima i u spornom dijelu i dalje bio na snazi.

Glede ustanova na području obrazovanja, Katolička Crkva ima pravo osnivati škole bilo kojega stupnja i predškolske ustanove te njima upravljati prema odredbama kanonskoga prava i zakonodavstva Republike Hrvatske. Takve

67 Narodne novine, br. 73/2013, 99/2013, 148/2013, 153/2013, 143/2014, 115/2016.

68 Sličan primjer možemo naći u Španjolskoj, u kojoj su Katolička Crkva i država ušli u pregovore nakon što je Europska komisija od Śpanjolske u prosincu 2005. godine zatražila da se i Katoličkoj Crkvi naplaćuje porez na dodanu vrijednost. Španjolska je odgovorila Komisiji da je takvo uređenje posljedica međunarodnog ugovora potpisanog prije pristupanja Španjolske EU-u te da Katoličkoj Crkvi ne može naplaćivati porez na dodanu vrijednost ako mu se ona dobrovoljno ne podvrgne. Komisija je odgovorila da pravo EU-a sili Španjolsku da upotrijebi sve prikladne mjere da eliminira nekompatibilnosti između EU-a i nacionalnog zakonodavstva. Španjolska je tada ušla u pregovore sa Svetom Stolicom koji su rezultirali (2007. godine) prihvaćanjem Katoličke Crkve da plaća porez na dodanu vrijednost, ali je zauzvrat dobila povećanje postotka poreza na dohodak koji se iz ukupnog poreza na dohodak pojedinca isplaćuje Katoličkoj Crkvi (s 0,52 \% na 0,7 \%). Vidi u: Celador Angon, O., Legal Aspects of the Financing of Religious Groups in Spain, The Age of Human Rights Journal, br. 2, 2014., str. 77 i 78. 
ustanove (s pravom javnosti) imaju pravo na primanje novčane potpore kako je predviđeno zakonodavstvom Republike Hrvatske. Republika Hrvatska osigurava novčana sredstva Katoličkom bogoslovnom fakultetu pri Sveučilištu u Zagrebu, s njegovim područnim studijima, odnosno afiliranim teologijama u Đakovu, Makarskoj, Rijeci i Splitu; a ako se osnuje novo crkveno visoko učilište, ono će imati pravo javnosti i za njega će Republika Hrvatska osiguravati odgovarajuća novčana sredstva. ${ }^{69}$

\section{KATOLIČKA CRKVA U REPUBLICI HRVATSKOJ I PRAVO EU-a - PROBLEMI I MOGUĆA RJEŠENJA}

Iz prethodne analize proizlazi da postoje nejasnoće u pravnom okviru Europske unije koji uređuje status Katoličke Crkve kao gospodarskog subjekta u kontekstu državnih potpora, kao i u nacionalnom pravnom okviru koji regulira ovo pitanje u Republici Hrvatskoj. Na europskoj razini, postojanje niza kriterija (od koji se neki uzimaju u obzir u određenim slučajevima, a drugi ne) na temelju kojih Sud Europske unije od slučaja do slučaja procjenjuje je li riječ o poduzetniku, odnosno gospodarskoj aktivnosti, ne doprinosi jasnoći pravnih normi EU-a za njihove adresate. $U$ tom kontekstu bitno je napomenuti da pravna sigurnost predstavlja opće načelo prava Europske unije ${ }^{70}$, a ono, inter alia, zahtijeva da pravna pravila budu jasna i predvidiva. ${ }^{71}$ Posljedično, ako već, zbog kompleksnosti teme, nije moguće unaprijed utvrditi koji će se kriteriji uzeti u obzir u

69 Dakako, riječ je o stanju sukladno Ugovoru u vrijeme njegova potpisivanja. Danas u Đakovu i Splitu postoji samostalni Katolički bogoslovni fakultet u okviru odnosnih sveučilišta. Teologija u Makarskoj pripojena je Katoličkom bogoslovnom fakultetu Sveučilišta u Splitu. Osim toga, na 5. redovitoj sjednici u akademskoj godini 2015./2016., održanoj 8. prosinca 2015., Senat Sveučilišta u Zagrebu donio je Odluku o uključenju Filozofskog fakulteta Družbe Isusove kao ustanove u sastav Sveučilištu u Zagrebu kao punopravne sastavnice pod nazivom Fakultet filozofije i religijskih znanosti. Treba navesti i da u okviru Sveučilišta u Zadru postoji poseban Teološko-katehetski odjel (počeo s radom akademske godine 2013./2014.). Osnovano je 3. lipnja 2006. godine (počelo s radom u akademskoj godini 2010./2011.) Hrvatsko katoličko sveučilište Dekretom o osnivanju Hrvatskog katoličkog sveučilišta sa sjedištem u Zagrebu br. 1273/2006. kardinala Josipa Bozanića, zagrebačkog nadbiskupa i mitropolita, kojemu, sukladno Ugovoru, dio materijalnih sredstava za rad osigurava Republika Hrvatska.

70 Vidi, primjerice, predmet C-381/97 Belgocodex SA v Belgian State [1998.], ECR I-8153, točka 26.

71 Vidi spojene predmete 212 do 217/80 Amministrazione delle finanze dello Stato v Srl Meridionale Industria Salumi and others; Ditta Italo Orlandi \& Figlio and Ditta Vincenzo Divella v Amministrazione delle finanze dello Stato [1981.], ECR 2735, točka 10. 
kojem pojedinačnom slučaju, propisivanje popisa kriterija koji se mogu uzeti u obzir bilo bi korak naprijed u smjeru jasnoće i predvidivosti propisa Europske unije u području djelovanja Katoličke Crkve kao gospodarskog subjekta. To je moguće provesti putem donošenja sekundarnog propisa EU-a, za što postoji više pravnih osnova koje predviđa Ugovor o funkcioniranju Europske unije. ${ }^{72}$

Predloženim sekundarnim propisom mogle bi se razriješiti i druge nejasnoće koje su istaknute u prethodnim poglavljima. To se posebno odnosi na situacije u kojima određeni subjekti, poput Katoličke Crkve, obavljaju široki spektar djelatnosti, od koji se neke u cijelosti ili djelomično financiraju iz javnih izvora, a druge od korisnika ili na druge (komercijalne) načine poput iznajmljivanja prostora trgovačkim društvima. Ovdje je posebno bitno razriješiti situacije u kojima određena ustanova pretežno obavlja negospodarsku djelatnost, a samo sporadično u manjem obujmu gospodarsku. U takvim situacijama potrebno je jasno (ako je moguće) kvantificirati različite aspekte djelatnosti ustanove i primijeniti tržišna pravila EU-a samo na one gospodarske. U hipotetskom primjeru dvorane u vlasništvu vjerske zajednice koja se 95 \% vremena koristi za obavljanje negospodarske obrazovne djelatnosti koju financira država, ta vjerska zajednica platila bi 5 \% poreza na građevinske radove od kojeg je oslobođena za negospodarski element svoje djelatnosti. Ako je nemoguće jasno odrediti omjer gospodarske i negospodarske djelatnosti, pitanje plaćanja poreza moglo bi se riješiti putem paušala pri čijem bi se određivanju uzeli u obzir različiti aspekti djelatnosti vjerske zajednice.

Što se tiče nacionalnog pravnog okvira, on je određen propisima od razine Ustava, međunarodnih ugovora do podzakonskih propisa. Navedeni propisi također zahtijevaju određena pojašnjenja u vezi sa statusom Katoličke Crkve kao (ne)gospodarskog subjekta u smislu prava Europske unije. Što se međunarodnih ugovora sklopljenih sa Svetom Stolicom tiče, njihove odredbe postavljene su dovoljno široko da se mogu tumačiti u svjetlu izričaja i svrhe prava EU-a, kao što je predviđeno praksom Suda Europske unije. ${ }^{73}$ To se ponajprije odnosi na čl. 10 Ugovora o gospodarskim pitanjima, prema kojem će se pravne osobe Katoličke Crkve u odnosu na porezni sustav smatrati neprofitnim ustanovama, što se ne primjenjuje na profitne djelatnosti pravnih osoba Katoličke Crkve. U tom smislu pojam "profitne djelatnosti" može se definirati u smislu gospodarskih djelatnosti prema pravu EU-a. Što se tiče odredbe o državnoj pomoći posebnim programima i projektima pravnih osoba Katoličke Crkve koji su korisni za opće dobro, ona se

72 Vidi čl. 109., 114. i 115. Ugovora o funkcioniranju Europske unije.

73 Vidi, primjerice, predmet C-106/89 Marleasing SA v La Comercial Internacional de Alimentacion SA [1990.], ECR I-4135, točka 8. 
također može tumačiti na način da se odnosi samo na negospodarske djelatnosti pravnih osoba Crkve (koje imaju socijalnu svrhu, utemeljene su na načelu solidarnosti i nemaju namjeru ostvarivanja dobiti), sukladno kriterijima europskog prava. Ovdje je bitna uloga Mješovite komisije Republike Hrvatske i Katoličke Crkve za rješavanje pravnih pitanja, čija je nadležnost, prema čl. 18. Ugovora o pravnim pitanjima, raspravljati o svim pitanjima od zajedničkoga interesa koja zahtijevaju nova ili dodatna rješenja. Komisija svoje prijedloge podastire mjerodavnim vlastima na odluku. Kroz njezino djelovanje mogu se predložiti i usvojiti jasni i transparentni kriteriji za razlučivanje između gospodarskih i negospodarskih djelatnosti Katoličke Crkve u Republici Hrvatskoj, koji bi bili obvezujući za tijela državne uprave (poput Porezne uprave) pri tumačenju relevantnih propisa iz njihove nadležnosti. Definiranje i objava navedenih kriterija svakako bi doprinijeli jasnoći i predvidivosti pravnog uređenja ovog područja, sukladno načelu pravne sigurnosti.

\section{ZAKLJUČAK}

Analiza europskog i nacionalnog pravnog okvira, u pogledu primjenjivosti tržišnih pravila Europske unije na Katoličku Crkvu, pokazala je da postoji više nejasnoća i potencijalnih točki prijepora na tu temu. To se ponajprije odnosi na primjenu različitih kriterija (od koji se neki uzimaju u obzir u određenim slučajevima, a drugi ne) prema kojima Sud Europske unije utvrđuje je li riječ u pojedinom slučaju o poduzetniku, odnosno obavlja li neki pravni subjekt gospodarsku djelatnost na koju su primjenjiva tržišna pravila EU-a, te na određene nedorečenosti u relevantnim propisima koji ovu tematiku uređuju na razini Republike Hrvatske. Konkretno, može se postaviti pitanje tumačenja čl. 10. Ugovora o gospodarskim pitanjima prema kojem će se pravne osobe Katoličke Crkve u odnosu na porezni sustav smatrati neprofitnim ustanovama, što se ne primjenjuje na profitne djelatnosti pravnih osoba Katoličke Crkve. Također, problematičnom se može smatrati odredba Ugovora o gospodarskim pitanjima koja obvezuje državu da na preporuku dijecezanskog biskupa svake godine razmotri, odobri i financijski pomaže posebne programe i projekte pravnih osoba Katoličke Crkve koji su korisni za opće dobro.

Opisane nedorečenosti i točke prijepora upućuju na potrebu jasnijeg reguliranja ovog područja sekundarnim europskim zakonodavstvom, kojim bi se propisao popis kriterija koji se uzimaju u obzir prilikom utvrđivanja je li u pojedinom slučaju riječ o gospodarskoj djelatnosti te razriješile situacije u kojima određena ustanova pretežno obavlja negospodarsku djelatnost, a samo sporadično u manjem obujmu gospodarsku. Osim navedenog, tumačenjem 
nacionalnih propisa s obzirom na izričaj i svrhu prava EU-a, za što je potrebno aktivnije djelovanje Mješovite komisije Republike Hrvatske i Katoličke Crkve za rješavanje pravnih pitanja, može se zaštititi načelo pravne sigurnosti i otkloniti prostor potencijalnim tvrdnjama da propisi koji u Republici Hrvatskoj uređuju pravni položaj Katoličke Crkve nisu u skladu s tržišnim pravilima Europske unije. Pojam "profitne djelatnosti” iz čl. 10. Ugovora o gospodarskim pitanjima može se definirati u smislu gospodarskih djelatnosti prema pravu EU-a, a odredba o državnoj pomoći posebnim programima i projektima pravnih osoba Katoličke Crkve koji su korisni za opće dobro može se tumačiti na način da se odnosi samo na negospodarske djelatnosti pravnih osoba Crkve (koje imaju socijalnu svrhu, utemeljene su na načelu solidarnosti i nemaju namjeru ostvarivanja dobiti), sukladno kriterijima europskog prava.

Međutim, čak i ako bi se pokazalo da postoji nekompatibilnost čl. 10. Ugovora o gospodarskim pitanjima i prava EU-a, Republika Hrvatska jedino može pokrenuti pregovarački postupak sa Svetom Stolicom u skladu s čl. 35l. st. 2. Ugovora o funkcioniranju EU-a kako bi se nekompatibilnost uklonila. Sve dok se taj pregovarački postupak ne dovrši dogovorom obiju strana, odredba čl. 10. Ugovora o gospodarskim pitanjima ostaje na snazi.

\section{LITERATURA}

Babić, M.; Kunštek, E., Neke dvojbe u primjeni Zakona o naknadi za imovinu oduzetu za vrijeme jugoslavenske komunističke vladavine - Pravna narav roka za pokretanje postupka / odnos prema Ugovoru Republike Hrvatske i Svete Stolice o gospodarskim pitanjima, Zbornik Pravnog fakulteta Sveučilišta u Rijeci, vol. 37, br. 1, 2016. str. 71 - 102.

Brugger, V., On the Relationship between Structural Norms and Constitutional rights in Church-State-Relations, u: Brugger, W.; Karayanni, M. (ur.), Religion in the Public Sphere: A Comparative Analysis of German, Israeli, American and International Law, Springer, Berlin - Heidelberg - New York, 2007., str. 21 - 86.

Cerovac, M, Pojam poduzetnika u pravu tržišnog natjecanja, Hrvatska pravna revija, br. 10, 2005., str. $60-70$.

Cerovac, M., Pravo tržišnog natjecanja u EU, u: Mintas Hodak, Lj., (ur.), Europska unija, MATE, Zagreb, 2010., str. 247 - 281.

Celador Angon, O., Legal Aspects of the Financing of Religious Groups in Spain, The Age of Human Rights Journal, br. 2, 2014., str. 68 - 85.

Đulabić, V., Socijalne službe u konceptu službi od općeg interesa, Revija za socijalnu politiku, vol. 14, br. 2, 2007., str. 137 - 162. 
Eterović, N., Ugovor između Svete Stolice i Republike Hrvatske o gospodarskim pitanjima, Crkva u svijetu, vol. 34, br. 1, 1999., str. 78 - 94.

Hatzopoulos, V., Killing National Health and Insurance Systems but healing Patients? The European Market for Health Care Services after the Judgements of the ECJ in Vanbraekel and Peerbooms, Common Market Law Review, vol. 39, br. 4, 2002., str. $683-729$.

Jakulj, I., Pravni položaj Katoličke Crkve u Republici Hrvatskoj: od totalitarizma do demokracije, Crkva u svijetu, vol. 50, br. 3, 2015., str. 478 - 513.

Jones, A.; Sufrin, B., EU Competition Law: Text, Cases and Materials, Oxford University Press, Oxford, 2014.

Jørgensen, S., The Right to Cross-Border Education in the European Union, Common Market Law Review, vol. 46, br. 5, 2009., str. 1567 - 1590.

Klarić, M.; Nikolić, M., Ustrojstvo javnih službi u Europskom pravnom poretku, Zbornik radova Pravnog fakulteta u Splitu, vol. 48, br. 1, 2011., str. 89- 102.

Kloosterhuis, E., Defining non-economic activities in competition law, European Competition Journal, vol. 13, br. 1, 2017., str. 117 - 149.

Louri, V., The FENIN Judgment: The Notion of Undertaking and Purchasing Activity, Legal Issues of Economic Integration, vol. 32, 2005., str. 87 - 97.

Miloš, M., Hrvatske vjerske zajednice u (protu) većinskoj prizmi svjetovne države, Zbornik Pravnog fakulteta Sveučilišta u Rijeci, vol. 35, br. 2, 2014., str. 651 - 677.

Odudu, O., Are State-Owned Health-Care Providers Undertakings Subject to Competition Law?, European Competition Law Review, vol. 48, br. 5, 2011., str. 231 - 241.

Poščić, A., Dokazivanje predatornih cijena u europskom pravu tržišnog natjecanja, Zbornik radova Pravnog fakulteta u Splitu, vol. 49, br. 3, 2012., str. 553 - 573.

Poščić, A., Pojam poduzetnika u europskom pravu tržišnog natjecanja, Zbornik Pravnog fakulteta Sveučilišta u Rijeci, vol. 29, br. 2, 2008., str. 917 - 939.

Staničić, F.; Ofak, L., Registracija vjerskih zajednica i vjerskih udruga u svjetlu Europske konvencije za zaštitu ljudskih prava i temeljnih sloboda, u: Šalković, J. (ur.), Vjernici, društva i pokreti, Glas koncila, Zagreb, 2011 ., str. 217 - 242.

Staničić, F., Pitanje povrata imovine oduzete Katoličkoj Crkvi i problema tumačenja Ugovora o pravnim pitanjima između Republike Hrvatske i Svete Stolice - pouke za budućnost u rješavanju odnosa crkve i države, u: Šarčević, E.; Bojić, D. (ur.), Sekularnost i religija: BiH i regija, Fondacija za javno pravo, Sarajevo, 2015., str. $193-212$.

Staničić, F., The Legal Status of Religious Communities in Croatian Law, Zbornik Pravnog fakulteta u Zagrebu, vol. 64., br. 2, 2014., str. 224 - 259. 
Svetlicinii, A., Back to the Basics: Concepts of Undertaking and Economic Activity in the Selex Judgment, European Law Reporter, vol. 12, 2009., str. 422 - 427.

Šinković, Z., Financiranje vjerskih zajednica (doktorska disertacija), Zagreb, 2015. Townley, C., The Concept of an 'Undertaking': The Boundaries of the Corporation A Discussion of Agency, Employees and Subsidiaries, u: Amato, G.; Ehlermann, C., (ur.), EC Competition Law: A Critical Assessment, Hart Publishing, Oxford, 2007., str. $3-24$.

Zrinščak, S., Religija i društvo, u: Kregar, J. et al., Uvod u sociologiju, Pravni fakultet u Zagrebu, Zagreb, 2014. 


\section{Summary}

\section{Tomislav Sokol * \\ Frane Staničić ${ }^{* *}$ \\ LEGAL STATUS OF THE CATHOLIC CHURCH AS AN ECONOMIC ENTITY IN EU AND CROATIAN LAW}

Regulation of the Catholic Church's legal status in the European Union primarily falls within the competences of the Member States. The Croatian legal framework in this respect consists of various types of legal rules, most important of which is the set of international agreements entered into between the Republic of Croatia and the Holy See. Still, EU competition, state aid and free movement rules affect this legal framework to a significant degree. The aim of this paper is to analyse the applicability of the said $E U$ rules to the activities of the Catholic Church in Croatia, that is to determine whether the Catholic Church can be considered an undertaking conducting an economic activity (and to what degree) according to the said legal framework, whether the Croatian national legal framework is aligned with the EU rules, and whether there are points of contention in this area which need to be legally rectified. The second part of this paper analyses the European Union state aid and free movement legal framework, primarily trying to determine whether the Catholic Church is an undertaking carrying out an economic activity as prescribed by EU law. In this analysis, several issues emerge which have not been clearly resolved by the Court of Justice. The following part features an outline of the Croatian national legal framework on the legal status of the Catholic Church, focusing on potential points of contention between the national and the EU law. Finally, certain solutions to the mentioned issues are proposed, on the European and the national level, in accordance with legal certainty as the general principle of (EU) law.

Keywords: Catholic Church, state aid, economic activity, undertaking

* Tomislav Sokol, Ph. D., Assistant Professor, senior lecturer, Zagreb School of Economics and Management; Assistant Professor, Croatian Catholic University; Jordanovac 110, Zagreb; tsokol@zsem.hr;

ORCID ID: orcid.org/0000-0002-3592-2967

** Frane Staničić, Ph. D., Associate Professor, Faculty of Law, University of Zagreb, Sv. Ćirila i Metoda 4, Zagreb; frane.stanicic@pravo.hr;

ORCID ID: orcid.org/0000-0001-8304-7901 